\title{
Seasonal Distributions, and Risk Assessment of Polychlorinated Biphenyls (PCBs) in the Surficial Sediments from the Turag River, Dhaka, Bangladesh
}

Nushrat Jahan Chowdhury

Jahangirnagar University

Mashura Shammi ( $\sim$ mashura926@juniv.edu )

Jahangirnagar University https://orcid.org/0000-0001-5449-4761

Md. Mostafizur Rahman

Jahangirnagar University

Md. Ahedul Akbar

BCSIR: Bangladesh Council of Scientific and Industrial Research

Md. Khabir Uddin

Jahangirnagar University

Research Article

Keywords: Bangladesh, PCBs, Sediments, Risk assessment, Turag River

Posted Date: May 17th, 2021

DOI: https://doi.org/10.21203/rs.3.rs-448430/v1

License: (c) (1) This work is licensed under a Creative Commons Attribution 4.0 International License.

Read Full License

Version of Record: A version of this preprint was published at Environmental Science and Pollution Research on February 12th, 2022. See the published version at https://doi.org/10.1007/s11356-02219176-0. 
Title

Seasonal Distributions, and Risk Assessment of Polychlorinated Biphenyls (PCBs) in the Surficial Sediments from the Turag River, Dhaka, Bangladesh

Nushrat Jahan Chowdhury ${ }^{\mathrm{a}}$, Mashura Shammi ${ }^{\mathrm{a}^{*}}$, Md. Mostafizur Rahman ${ }^{\mathrm{a}^{*}}$, Md. Ahedul Akbor $^{b^{*}}$, Md. Khabir Uddin ${ }^{\mathrm{a}}$

aDepartment of Environmental Sciences, Jahangirnagar University

${ }^{\mathrm{b}}$ Institute of National Analytical Research and Services, Bangladesh Council of Scientific \& Industrial Research

*Corresponding authors: mashura926@juniv.edu; rahmanmm@juniv.edu; akborbcsir@gmail.com

\section{Abstract}

Polychlorinated biphenyls (PCBs) assessment in sediments of Turag River, Dhaka, Bangladesh has been conducted for the first time. This River provides critical ecological services to agriculture, industry, and transportation. However, the Turag River is one of the most industrially polluted rivers surrounding Dhaka in Bangladesh. In this study, six PCB congeners namely PCB 10, PCB 28, PCB 52, PCB 138, PCB 153, and PCB 180, were analyzed in surface sediments by GC-ECD at 9 sampling sites. Pre-monsoon and post-monsoon season sampling were collected in this study. The total concentrations of PCBs varied from 344.49 to $0.22 \mathrm{ng} / \mathrm{g} \mathrm{dw}$ and 10.6 to $1.68 \mathrm{ng} / \mathrm{g} \mathrm{dw}$ in pre-monsoon and post-monsoon, respectively. The paramount contributor congener to the total PCBs was PCB 180 and was found at all sites. The ecological risk assessment indicated a high potential risk in pre-monsoon $\left(E_{r}^{i}=277.32\right)$ and low potential risk in post-monsoon $\left(E_{r}^{i}=25.69\right)$.

2 Sediment quality guideline quotients (SQGQs) showed that PCBs in pre-monsoon would cause no or moderate biological effects on organisms at most sampling sites except in surface sediments of 
24 site S5 (high biological effects), while no adverse ecotoxicological effect was observed in post-

25 monsoon. Considering both probable effect level (PEL) and threshold effect level (TEL), the new

26 sediment quality guideline quotient (NSQGQ) showed that in post-monsoon PCBs contamination

27 would cause moderate biological effects, while in pre-monsoon the findings remained consistent

28 with the findings of SQGQ. This study gave a quick look at the PCB contamination scenario in the

29 Turag River sediments and also allowed for a comparison between the investigated River and other

30 rivers worldwide.

32 Keywords: Bangladesh; PCBs; Sediments; Risk assessment; Turag River

\section{1. Introduction}

36 Polychlorinated biphenyls (PCBs) are a type of man-made chlorinated compounds consisting of

37209 congeners known as persistent organic pollutants (POPs) originally appended in the

38 Stockholm Convention on POPs. In the 1930s-1980s, PCBs were widely manufactured around the

39 world as commercial mixtures because of their low flammability, thermal and chemical stability,

40 and electric insulating properties (Kampire et al. 2017). For many years, PCBs were extensively

41 used as dielectric fluids in capacitors and transformers, pesticide and wax extenders, printing ink,

42 carbonless copy paper, hydraulic oils, flame retardants, coolants, adhesives, and in various

43 applications (ATSDR 2000; Habibullah-Al-Mamun et al. 2019). Though PCBs have been banned

44 in the late 1970s, worldwide they are still reported in environmental matrixes e.g., water, air, 45 sediments, etc., in various studies. 
46 Sediments serve as reservoirs for PCBs as being absorbed by them (Ranjbar Jafarabadi et al. 2019).

47 When PCBs are transported into the aquatic environment through the diverse paths, they tend to 48 deposit on the surface sediments and a small portion of PCBs adsorbed on the suspended 49 particulate matter in water (Mechlińska et al. 2010). Then, these sediments bound contaminants 50 are carried away through incorporating with trophic level e.g., consumption of benthic organisms

51 by fish (Bjermo et al. 2013). Again, sediment can resuspend with changes in environmental 52 components, and then be released back into the water and begin another cycle of environmental 53 contamination and may end up in the food chain (Cui et al. 2020). Therefore, the surface sediments 54 show the current PCBs contamination levels in the river (Baqar et al. 2017).

55 Bangladesh is a signatory country to the Stockholm Convention on POPs, 2001. But environmental 56 quality guideline on PCBs has barley been set in Bangladesh. However, in Bangladesh, some 57 studies have been carried out to evaluate the PCBs contamination in environmental media and 58 biota at the coastal areas. Yet, no researches have been conducted on PCBs pollution on any river 59 body. Also, the occurrence and ecotoxicological risks of this compound in various river sediments 60 are remained unknown.

61 Turag is one of the most polluted rivers running through west-north and north of Dhaka City (Islam 62 et al. 2018; Ferdousi et al. 2020). This River is directly affected by various industries ranging from 63 small to large scale garments, textile, pharmaceuticals, chemicals, pesticides, jute, metal industries,

64 tobacco, ink, pulp and paper mills, food processing, tanneries, etc. (Sarkar et al. 2016; Aktar and 65 Moonajilin 2017; Islam et al. 2018). The heavy discharge of pollutants by the industries adjacent 66 to the River banks causes a dangerous level of water abysmal (Begum et al. 2018). The Department 67 of Environment (DoE) declared it as an ecologically critical area (ECA) in September 2009 68 (Rahman et al. 2018; Majed and Chawdhury 2018). 
69 The process of urbanization, industrialization, and medium to large-scale landfills using industrial

70 sludges, open burning of industrial and municipal waste, e-waste, etc., and many other polluting

71 activities on riverbanks might be the key sources of PCBs in this River. Besides, the tropical

72 climate of Dhaka causes frequent rainfall with an annual average temperature of $25{ }^{\circ} \mathrm{C}$ might

73 attribute to the transportation of contaminants to this River. Thus, the contamination status of PCBs

74 and its harmful consequences are paramount to evaluate seasonally and spatially in the River

75 sediments. Very few studies have been carried out regarding organic pollutants on the River, and

76 ecological risks due to organic pollutants are still unknown. Hence, the consensus-based sediment

77 quality guideline (SQG) given by Long and MacDonald (1998) has been extensively used to assess

78 PCBs induced ecotoxicological risks in sediments (Barakat et al. 2013; Zhang et al. 2016; Liber et

79 al. 2019). Therefore, the prime objectives of this study were to assess the seasonal and spatial

80 distribution of sedimentary PCBs pollution and to evaluate the ecological and ecotoxicological

81 risk of PCBs in sediment.

\section{2. Materials and Methods}

\section{$83 \quad 2.1$ Study area and sample collection}

84 The study area consists of the part of the Turag River. The Turag River is one of the most

85 prominent floodplain regions generates from the Bangshi river at Kaliakoir Upazila (Hossain and

86 Chowdhury 2018). The Turag River is active and has a small flow only in the dry season. It joins

87 the Buriganga River near Mirpur (Dhaka) (Aktar and Moonajilin 2017; Hossain and Chowdhury

88 2018). It is navigable by boats throughout the year (Islam et al. 2018).

89 Two sampling trips were undertaken in pre-monsoon (March-May) 2019 and in post-monsoon

90 (November-February) 2020 to collect surface sediments on the bank of the Turag River (Fig. 1). 
91 During low tide, a total of 18 sediment samples were collected during this time from nine sampling

92 sites. From the top surface $(0-6 \mathrm{~cm})$ of the riverbank, around $200 \mathrm{~g}$ of sediments were collected

93 from each location by a hand Trowel as a sampler. In polyethylene (PE) ziplock bags the samples

94 were carried and transferred in an airtight ice-filled insulating box.

95 The samples were stored at $-8^{\circ} \mathrm{C}$. All the samples were air-dried for two days, and foreign objects

96 such as leaves, shells, plastic fragments, and other visible impurities were discarded. Subsequently,

97 a mortar and a pestle were used to ground the dried sediments. Then, these were sieved for

98 homogenization by using a stainless-steel sieve (Testing Sieve, Chung gye, Seoul, Korea) (1 mm)

99 and resulted in fine powder. The powder was then transferred into polyethylene (PE) ziplock bags

100 and kept in a freezer at $-20^{\circ} \mathrm{C}$ before extraction.

\section{$101 \quad 2.2$ PCBs Extraction and Clean-up}

102 The APA 6431B method was followed to extract the target compounds from the sediment samples.

103 Briefly, $50 \mathrm{~mL}$ of $\mathrm{n}$-hexane and $50 \mathrm{~mL}$ of acetone were introduced into a $250 \mathrm{~mL}$ conical flask

104 containing $10.0 \mathrm{~g}$ of the sediment sample and sonicate vigorously for 60 minutes. The sample was

105 filtered into a $250 \mathrm{~mL}$ round bottle flask. The procedure was repeated twice. The extracts were

106 later combined to make a whole and concentrated to $1 \mathrm{~mL}$ using a rotary evaporator in a water

107 bath at $35^{\circ} \mathrm{C}$. The remains were moved into a $10 \mathrm{~mL}$ test tube with $5 \mathrm{~mL}$-hexane with anhydrous

$108 \mathrm{Na}_{2} \mathrm{SO}_{4}$. Here, clean-up was done by adding $1 \mathrm{~mL}$ of Sulphuric acid with $10 \%$ water; shaken

109 vigorously using a vortex mixer for $1 \mathrm{~min}$, and then centrifuge at $3000 \mathrm{r} / \mathrm{min}$ to separate the two

110 layers recording the volume collected in GC vial for the run.

\section{$111 \quad 2.3$ GC-ECD Analysis}


112 The quantification of polychlorinated biphenyls (PCBs) was performed by injecting $1.0 \mu 1$ aliquot

113 of final extract into a gas chromatograph (Simadzu 2010 plus) equipped with a ${ }^{63} \mathrm{Ni}$ electron

114 capture detector (ECD) and a moving needle-type injection system and injection mode was

115 splitless. The column consisted of SH Rtx-5, $30 \mathrm{~m}$ long, $0.32 \mathrm{~mm}$ i.d.0.25 $\mu \mathrm{m}$ film thickness. Here,

116 the column temperature was started from $120^{\circ} \mathrm{C}(1 \mathrm{~min}$ hold $)$ at a rate of $20^{\circ} \mathrm{C} / \mathrm{min}$ to $210{ }^{\circ} \mathrm{C}(4$

$117 \mathrm{~min}$ hold $)$ and then at a rate of $5{ }^{\circ} \mathrm{C} / \mathrm{min}$ to $290^{\circ} \mathrm{C}(3 \mathrm{~min}$ hold $)$. Detector and injector temperatures

118 were maintained at $300{ }^{\circ} \mathrm{C}$ and $200{ }^{\circ} \mathrm{C}$ respectively. Nitrogen gas was the carrier gas

119 Data acquisition and processing were carried out by a chromatogram, named GCsolution Postrun,

120 Version 2.41 .00 with a workstation (GCsolution), and a computer. PCBs were quantified by

121 comparing the individual peak areas between the sample and the standard.

\section{$122 \quad 2.4$ Quality assurance and quality control}

123 For the study of linear range, a diluted PCBs standard mixture solution series of 2.5, 5, 10, 50, 100,

124 and $200 \mathrm{ng} / \mathrm{mL}$ were prepared and injected onto the GC-ECD. The results show that the relation

125 is linear up to $200 \mathrm{ng} / \mathrm{mL}$ and the coefficients of determination $\left(\mathrm{R}^{2}\right)$ values showed good linearity 126 ranging between 0.9844 and 0.9971 .

127 All solvents were of analytical grade for PCBs analysis. Quality assurance (QA) and quality 128 control (QC) measures are baking all glassware at $400{ }^{\circ} \mathrm{C}$ and rinsing them with solvent before 129 use, running method blanks, and matrix blanks for every batch of 10 samples. An S/N (signal-to130 noise) ratio equivalent to 10 was applied to set the limit of detection (LOD) for each analyte. The

131 limit of detection (LOD) was ranged from $0.01 \mathrm{ng} / \mathrm{mL}$ (dw) to $200 \mathrm{ng} / \mathrm{mL}$ (dw). $<0.001 \mathrm{ng} / \mathrm{g}$ levels

132 were taken as not detected in the PCB calculations. Moisture content was assessed to present data 133 on a dry weight basis. 


\section{$134 \quad 2.5$ Data analysis}

135 For statistical analyses, IBM SPSS Statistics (Version 22.0) and Microsoft XL (Version Microsoft

136 Office Professional Plus) were employed. The Shapiro-Wilk W test was conducted for data

137 normality test. One-way ANOVA test was conducted to find the variations among the 138 concentrations of PCBs and seasonal differences. The Arc-GIS software (Version 10.5) was used

139 for site identifications and the spatial variations of PCBs in sediments.

\section{$140 \quad$ 2.6 Sediment quality guideline quotient (SQGQ)}

141 SQGQ was carried out to identify the adverse biological effects of PCBs in sediments. Firstly, the

142 probable effects level quotient (PELQ) was calculated by applying the following formula (Long

143 and MacDonald 1998):

$144 P E L Q_{i}=\frac{C_{i}}{P E L}$

145 where PEL is the guideline value for the target contaminant (i), and $C_{i}$ is the measured 146 concentration of the target contaminant. For each site, the SQGQ was calculated as:

$147 \quad S Q G Q=\frac{\sum_{i=1}^{n} P E L Q_{i}}{n} \ldots \ldots \ldots \ldots(2)$

148 where $\mathrm{n}$ is the total number of measured contaminants having sediment quality guideline values.

149 Three ranges of SQGQ were categorized based on potential adverse biological effects of sediment 150 contamination. They are: no biological effects (SQGQ $<0.1)$, moderate biological effects $(0.1 \leq$

151 SQGQ $<1$ ), and high biological effects (SQGQ $\geq 1$ ) (Tian et al. 2013; Wang et al. 2019; Lv et al. 152 2020).

$153 \quad 2.7$ New sediment quality guideline quotient (NSQGQ) 
154 According to Wang et al., 2019, SQGQs might depreciate the risks of PCBs for not taking into 155 consideration the TEL effects. Thus, considering both PELs and TELs, they introduced a new 156 sediment quality guideline quotient (NSQGQ) (Long and MacDonald 1998; Zhang et al. 2016). 157 At first, NSQGQ for total PCB congeners was derived from the following formula (Wang et al. 158 2019):

$N S Q G Q_{i}=\frac{\sqrt{\frac{C_{i}}{T E L}}+\left(\frac{C_{i}}{P E L}\right)^{2}}{2}$

160 Finally, the combined toxic risk index of total PCBs and other contaminants could be assessed

161 based on the following equation:

$162 N S Q G Q=\frac{\sum_{i=1}^{n} N S Q G Q_{i}}{n} \ldots \ldots \ldots \ldots \ldots . . .(4)$

163 Where $N S Q G Q_{i}$ is the new SQGQ of a certain contaminant; $C_{i}$ denotes the measured concentration

164 of the target contaminant; $\mathrm{n}$ denotes the total number of the measured contaminants having

165 sediment quality guideline values and NSQGQ refers to the combined new sediment quality 166 guideline quotient.

\section{3. Results and discussion}

\subsection{Composition and occurrence of PCBs in sediments}

169 In the present study, detectable levels of PCBs were noticed in all sedimentary samples. The PCB

170 congeners concentration in sediments from Turag are presented in Table 1. The PCB 171 concentrations ranged from 0.217 to $344.49 \mathrm{ng} / \mathrm{g}$ and 1.68 to $10.6 \mathrm{ng} / \mathrm{g}$ dry weight (dw) in pre172 monsoon and post-monsoon, respectively in the surface sediments. 
173 In pre-monsoon, the highest concentration $(344.49 \mathrm{ng} / \mathrm{g})$ was observed in sediments collected from

174 Site 5 with the only presence of PCB 180 (344.412 ng/g dw) and PCB 52 (0.074 ng/g dw) (Table

175 4.1). Followed by Site 5, both Site 3 and 8 were higher in PCB concentrations. For Site 8 and 3 , 176 the concentrations were $124.82 \mathrm{ng} / \mathrm{g}$ and $121.18 \mathrm{ng} / \mathrm{g}$, respectively.

177 The percentage composition of six PCB congeners is shown in Fig. 2. In pre-monsoon, PCB 180 178 was the most abundant among the analyzed congeners with an average concentration of $17967.67 \pm 115.6 \mathrm{ng} / \mathrm{g}$ in the investigated samples, followed by PCB $28(0.786 \pm 2.17 \mathrm{ng} / \mathrm{g})$ and PCB $180138(0.441 \pm 0.68 \mathrm{ng} / \mathrm{g})$. PCB 180 alone contributed more than $97 \%$ to the total PCBs in the 181 analyzed sediments. PCB 180 showed predominance at all sites. From Fig. 2(a), PCB 52 was the 182 second dominant congener at Sites 7 and 9. PCB 28 was the second dominant congener at Sites 1 183 (> 40\%) and 2. Also, PCB 138 was the second dominant congener at Sites 4 and $6(>15 \%)$.

184 Whereas, in post-monsoon (Fig. 2(b)), PCB 180 was the most abundant congener with an average 185 concentration of $4.38 \pm 2.78 \mathrm{ng} / \mathrm{g}$, followed by PCB $28(.86 \pm 2.48 \mathrm{ng} / \mathrm{g})$ and PCB 52. Here, PCB 186180 alone contributed more than $68 \%$ to the total PCBs in the analyzed sediments. From Fig. 187 4.1(b), PCB 180 showed predominance at all sites except Sites 1 and 8. PCB 10 showed 188 predominance at Site 8 (> 40\%), and PCB 28 showed predominance at Site $1(>60 \%)$. PCB 52 189 was the second dominant congener at Sites 4, 5, 6, and 7.

190 High abundance and dominance of PCB 180 had been observed in both seasons. In the past, 191 increased concentrations of PCBs 170 and 180 have been reported to be evidence of the presence 192 of Aroclor 1260 (Ormerod et al. 2000). Aroclor 1260 was a usual constituent of capacitor oils and 193 transformer (Erickson and Kaley 2011). This would be consistent with the release from the 194 disassembling of transformers and other types of electrical equipment at Sites 3, 5, and 8 in the 
195 pre-monsoon season. Both Sites 5 and 8 were in the vicinity of landfills. Especially at Site 5,

196 several transformers were observed along the roadsides. Leakage from these transformers may be

197 concentrated due to heavy rainfall accompanied by Cyclone Fani in the same month and lead to

198 the high contamination of PCB 180.

199 PCBs are conclusively a significant source of environmental pollution because of leakage from

200 installations at storage or disposal, operating installations, and considered a great source of

201 environmental pollution by PCBs in several emission inventories (Kakareka and Kukharchyk

202 2005). During the site visit, it was observed that maximum sites direct in contact with landfills.

203 Landfills are a potential source of PCBs emission, as they contain municipal and industrial wastes.

204 The type of PCB wastes in the landfills highly affects the levels of PCBs emissions (Kakareka and

205 Kukharchyk 2007). Municipal waste burning is another potential source of PCBs pollution in this

206 study. A variety of wastes are burnt into large bonfires such as paper, packaging material,

207 paperboard, polyethylene film, plastic bottles, contaminated wood, waste food, rags, etc. Street

208 sweep which contains a significant share of domestic wastes is burnt down often. Sanitary landfills

209 of solid wastes and in other places of their unofficial accumulation cause unavoidable spontaneous

210 fires.

\section{$211 \quad 3.2$ Seasonal and spatial differences of PCBs in sediments}

212 In the study area, the seasonal and spatial dissemination of PCBs in sediments are shown in Fig.

213 3. Seasonally, neither the levels of total PCBs nor the identified congeners distribution patterns

214 differ significantly $(\mathrm{p}>0.05)$.

215 Sediments are heterogeneous in constituents, and the different elements of sediments show 216 different interactions with the pollutants (Kampire et al. 2017). It may highly affect the 
217 composition of PCBs concentration spatially and seasonally. Only Site 1 exhibited a little bit

218 consistent during two seasons (14.86 ng/g and $10.6 \mathrm{ng} / \mathrm{g}$ in pre-monsoon and post-monsoon,

219 respectively). It indicates the sources of PCBs might be similar in both seasons (Dodoo et al. 2012;

220 Habibullah-Al-Mamun et al. 2019).

221 The seasonal difference in the PCBs concentration might be caused by the variations of the 222 precipitation amount in these two seasons ( $\mathrm{Li}$ et al. 2012). The elevated levels of PCBs in pre223 monsoon samples, especially at Sites 3, 5, and 8 might be caused by heavy rainfall and floods 224 which triggered surface runoff from highly contaminated sites. This reason is suspected because 225 heavy rainfalls took place due to Cyclone Fani before sampling from these sites. This tropical 226 cyclone caused medium to heavy rainfall over the country, and Dhaka experienced $1070 \mathrm{~mm}$ 227 rainfall accompanied by the tropical cyclone (The Daily Star 2019; OCHA 2019). Large water 228 bodies show higher contamination during and immediately after rainstorms (Awwa Research 229 Foundation 2008). An increase in precipitation intensity triggers inputs of pollutants, especially 230 severe nutrients, pathogens, hazardous substances, organic material, and other dissolved 231 contaminants (e.g., pesticides) (Ching et al. 2015). On the day of sample collection in the pre232 monsoon season, at Mirpur station (SW302) the water level was $2.86 \mathrm{~m}$ with regular water flow. 233 Intense shipping and fishing activities during the pre-monsoon season might be another reason for 234 PCBs contamination.

235 In premonsoon, higher levels of PCBs were observed at Site 2 (10.54 ng/g), Site 4 (9.67 ng/g), and 236 Site $6(5.38 \mathrm{ng} / \mathrm{g})$. Co-evaporation of PCBs with water might be one of the reasons (Dodoo et al. 237 2012). Another reason might be excessive sedimentation from low mixing effects in the dry season 238 because of relatively weaker wave action and decreased upstream rivers inflow (Habibullah-Al239 Mamun et al. 2019). It is important to note that the dry flow during post-monsoon decreased the 
240 water height to such extent that some of the samples were stored from the river bed and the water

241 level was $1.52 \mathrm{~m}$ with low water flow at the Mirpur station (SW302).

242 Despite sampling sites in the study area, the mean concentration of $\sum$ PCBs in pre-monsoon (69.33

$243 \mathrm{ng} / \mathrm{g} \mathrm{dw})$ was much higher than in post-monsoon $(6.42 \mathrm{ng} / \mathrm{g} \mathrm{dw})$. The findings were compatible

244 with earlier research conducted by Lai et al., in 2015 at Pearl River, China which reported that the

245 wet season has a higher mean concentration of $\sum \mathrm{PCBs}$ than the dry season, and which was not

246 significant $(\mathrm{P}>0.05)$. In several studies, $\mathrm{PCB}$ concentration remains the same or slightly changes

247 over seasons (Baqar et al. 2017; Habibullah-Al-Mamun et al. 2019).

248 The spatial distribution of $\sum$ PCBs deviated highly from the mean concentration of $\sum$ PCBs in pre249 monsoon $(\mathrm{SD}=115.12 \mathrm{ng} / \mathrm{g})$. High tidal influence, high precipitation, changes in river dynamics 250 might affect the spatial distribution of pollution in pre-monsoon. Besides, agricultural and surface 251 runoffs, dumping of industrial wastes, intense dredging operations, and atmospheric depositions 252 might speed up the extent of PCB contamination in this season. Whereas, in post-monsoon, the 253 spatial distribution of $\sum$ PCBs did not deviate highly from the mean concentration of $\sum$ PCBs (SD $254=3.37 \mathrm{ng} / \mathrm{g})$. Weak tidal influence, low water flow, low or no precipitation, static river dynamics 255 might affect the spatial distribution of pollution in this season. During the monsoon season (June 256 to Mid-October), the surface sediments generally are worn out and new sediments are settled down 257 thereafter. It takes time to accumulate organic pollutants in new sediments. Consequently, 258 relatively very lower concentrations of PCBs were observed in the post-monsoon season.

259 The incomplete burning of e-wastes is a potential source of PCBs in the study area. Other potential 260 sources of PCBs in the study area might contain paint industry, burning of e-waste for metal 261 recovery, vehicular fuels, PVC (polyvinyl chloride) industries (Syed et al. 2014; Baqar et al. 2017), 
262 dumping and discharges of oils and waste material (Farooq et al. 2011), coal combustion and

263 industrial waste (Chi et al. 2007), and recycling units and steel production (Biterna and Voutsa

264 2005),

\section{4.4 Ecological risk assessment}

266 It is highly important to assess the sediment-bound PCBs inducing potential risk of the Turag

267 River. As there is still no uniform standard available, the risk assessment of PCBs in the riverine

268 environment was carried out based on the ecological risk index (ERI) of Hakanson (1980) and

269 implemented in previous studies (Cui et al. 2016; Baqar et al. 2017). Here, the risk assessment has

270 been done by the following equations:

$271 \quad E R I=\sum E_{r}^{i}$

$272 E_{r}^{i}=T_{r}^{i} \times C_{f}^{i}$

$273 \quad C_{f}^{i}=\frac{C_{0}^{i}}{C_{n}^{i}}$

274 Where ERI is the summation of ecological risk factors of seven heavy metals and PCBs. As this

275 study is about PCBs, so heavy metals were disregarded. So, in this calculation, ERI is equivalent

276 to $E_{r}^{i}$ (monomial potential ecological risk factor). $T_{r}^{i}$ is the toxic-response factor for PCBs. $C_{f}^{i}$ is

277 the contamination factor, and $C_{n}^{i}$ denotes reference value for $\sum \mathrm{PCBs}$, and it is $0.01 \mathrm{ppm}$ or 10 $278 \mathrm{ng} / \mathrm{g}$.

279 The potential ecological risk factor $\left(E_{r}^{i}\right)$ had been graded into following five categories

280 (Hakanson, 1980): $E_{r}^{i}<40$, low risk; 40-79 $E_{r}^{i}$, moderate risk; 80-159 $E_{r}^{i}$, considerable risk;

$281 \quad 160-319 E_{r}^{i}$, high risk; and $E_{r}^{i}>320$, very high risk. 
282 The ERI was calculated using Eqs. (3) and (4). The ERI value indicated high potential ecological

283 risk during pre-monsoon $\left(E_{r}^{i}=277.32\right)$ and low potential ecological risk during post-monsoon

$284\left(E_{r}^{i}=25.69\right)$. The ecological risk factor of the Turag River is shown in Table 2.

\section{$285 \quad 4.5$ Ecotoxicological risk assessment}

286 4.5.1 Sediment Quality Guideline Quotients (SQGQs)

287 The average values of SQGQ for both seasons are shown in Fig. 4.5. Six sampling sites of pre-

288 monsoon are below 0.1. Besides, the SQGQs in two sampling sites, namely, Site 3 and Site 8

289 indicate the benthic organisms might suffer from moderate adverse biological effects due to

290 sediment-bound PCBs. The SQGQ of PCBs at Site 5 is above 1, suggesting that this surface

291 sediment of the sampling site was suffering from high adverse biological effects (Table 3).

292 Whereas, the SQGQs of post-monsoon show that PCBs would not cause any effects on benthic

293 organisms (Table 3).

\section{$294 \quad$ 4.5.2 New sediment quality guideline quotient (NSQGQ)}

295 Wang et al., 2019 showed in their study that there was a significant linear correlation $\left(\mathrm{R}^{2}=0.9869\right.$,

$296 \mathrm{p}<0.01$ ) between SQGQs and NSQGQs while specifying that NSQGQs perhaps a valid method

297 to evaluate the ecotoxicological risks of PCBs. They recommend NSQGQs can better estimate the

298 ecotoxicological risks for PCBs. Here, the effect levels were divided into the following categories:

299 NSQGQ $<0.2$, no or low effects; $0.1 \leq$ NSQGQ $<2$, moderate effects; and NSQGQ $\geq 2$, high

300 adverse effects.

301 In pre-monsoon, the NSQGQs reflect that the PCBs contamination would cause low to moderate

302 biological effects on the Turag River except Site 5 indicating a high adverse effect on biological

303 organisms (Table 3). Whereas, in post-monsoon, the NSQGQs denote that PCBs contamination 
304 caused moderate biological effects during the post-monsoon, while according to SQGQ, this

305 season had no effects on aquatic species of the Turag River (Table 3).

\section{$306 \quad 4.6$ Comparison with previous studies worldwide}

307 A comparison of mean sedimentary $\sum$ PCBs concentration of the Turag River with those recorded

308 from other rivers around the world is presented in Table 4.

309 No data on PCB contamination in the Turag River is accessible to compare with the findings of

310 other studies in sedimentary PCBs. In Bangladesh, the literature indicates no research on riverine

311 sedimentary PCBs.

312 The comparison of mean PCBs concentration in sediments of Pre-monsoon with other studies

313 (Table 4) presented that the $\sum$ PCBs concentration of this study was comparable or lower than those

314 reported from Huveane River, France (Kanzari et al. 2014); Umgeni River, South Africa (Gakuba

315 et al. 2015); Pearl River Delta, China (Wang et al. 2019); and Pangani River and its tributaries,

316 Tanzania (Hellar-Kihampa et al. 2013).

317 Whereas, the comparison of the mean PCBs concentration in sediments of Post-monsoon with 318 other studies showed that the $\sum$ PCBs concentration of this study was significantly lower than those 319 reported from Makelele, Kalamu, and Nsanga, Congo (Kilunga et al. 2017); River Ravi, Pakistan 320 (Baqar et al. 2017); Liaohe River, China (Lv et al. 2020); CauBay River, Vietnam (Toan and Quy 321 2015); Sarno River, Italy (Montuori et al. 2014); Soan River, Pakistan (Malik et al. 2014); and 322 River Chenab, Pakistan (Eqani et al. 2012). However, the $\sum$ PCBs concentration was slightly lower 323 or somewhat comparable to those studies recorded from River Thames, England (Lu et al. 2017);

324 Yamuna River, India (Kumar et al. 2013); Songhua River, China (Cui et al. 2016) and Bahlui 325 River, Romania (Neamtu et al. 2009). 
326 The total sedimentary PCBs levels reported from developed countries (China, England, France,

327 Italy, and South Africa) were generally a little comparable or higher than the total PCBs levels in

328 the present study. This suggests that eminent industrial activities, and a variety of waste discharges

329 in the environmental compartments of developed countries (Kampire et al. 2017). Whereas, the

330 levels of total PCBs on the river sediments from developing countries (Egypt, Vietnam, Romania,

331 and Mexico) were generally comparable or lower than the total PCBs levels in the present study.

332 The history of PCBs is prevalent and more extensive in developed nations than in developing

333 countries, and the contamination seems to be more profound in developed countries (Mochungong

334 and Zhu 2015).

335 4. Conclusion

336 The present study was the first to focus on the levels of PCB organic pollutants in the surficial

337 sediments of the Turag River, Dhaka, Bangladesh. PCB 180 was the most conspicuous one in

338 sediments during both seasons. Considering seasonal variation, the mean concentration of $\sum$ PCBs

339 in pre-monsoon $(69.33 \mathrm{ng} / \mathrm{g} \mathrm{dw})$ was higher than in post-monsoon $(6.42 \mathrm{ng} / \mathrm{g} \mathrm{dw})$. Sites 3,5 , and

3408 in pre-monsoon were subjected to moderate to high adverse biological effects on benthic

341 organisms. Ecological risk assessment reflected high potential ecological risk in pre-monsoon $\left(E_{r}^{i}\right.$

$342=277.32)$ and low potential ecological risk in post-monsoon $\left(E_{r}^{i}=25.69\right)$. The sedimentary PCB

343 concentrations of the investigated area were comparable with rivers around the world.

344 The possible sources of PCBs are from dyeing, chemicals, paper mills, domestic industrial and

345 wastewater discharge from factories, (e.g., paper, paint, iron, and textile factories) of industrial

346 clusters. The sources also include landfills, e-wastes, transformers, constructions and demolition

347 wastes, municipal waste open burning, etc. into the Turag River. In the lack of any data on PCBs

348 in the study area, the present study will yield baseline data for subsequent ecological studies in the 
349 future. Again, this study will put stress on the assays of Bangladesh's national implementation

350 plan (NIP) to the exclusion of PCBs as being a party of the Stockholm Convention, 2001.

\section{Acknowledgments}

352 The authors convey their deepest appreciation to the Ministry of Science and Technology,

353 Government of the People's Republic of Bangladesh and Water Research Center, Jahangirnagar

354 University for finance and support to conduct the study. The authors also recognize the assistance

355 from M. M. Rashid, M. R. Karim, and S. F. Sharmin during sampling and I. Jerin and H. Mahmud 356 during sample analysis.

\section{Author's Contribution}

358 NJC, MS, and MKU designed and planned the study. NJC collected and analyzed the samples.

359 MAA supported all lab analyses. NJC prepared the draft manuscript. MS and MMR did proof 360 reading.

\section{Declarations}

362 Availability of Data and Materials The authors confirm that the data supporting the findings of 363 this study are available within the article.

364 Ethics approval and consent to participate Not applicable.

365 Consent for publication All the authors approved the manuscript for publication.

366 Competing interests The authors declare that they have no competing interests.

367 References

368 Aktar P, Moonajilin MS (2017) Assessment of Water Quality Status of Turag River Due to 
Industrial Effluent. Int J Eng Inf Syst 2017:105-118. https://hal.archives-ouvertes.fr/hal01580938

371

372

373

374

375

376

377

378

379

380

381

382

383

ATSDR (2000) Toxicological profile for polychlorinated biphenyls (PCBs). United States Department of Health and Human Services, Public Health Service, Agency for Toxic Substances and Disease Registry. https://www.atsdr.cdc.gov/toxprofiles/tp17.pdf

Awwa Research Foundation (2008) Effects of Climate Change on Public Water Suppliers. https://www.sigmaxi.org/docs/default-source/Programs-Documents/water-whitepapers/awwa.pdf?sfvrsn=11fcad58_2. Accessed 25 February 2021

Baqar M, Sadef Y, Ahmad SR, et al (2017) Occurrence, ecological risk assessment, and spatiotemporal variation of polychlorinated biphenyls (PCBs) in water and sediments along River Ravi and its northern tributaries, Pakistan. Environ Sci Pollut Res 24:27913-27930. https://doi.org/10.1007/s11356-017-0182-0

Barakat AO, Khairy M, Aukaily I (2013) Persistent organochlorine pesticide and PCB residues in surface sediments of Lake Qarun, a protected area of Egypt. Chemosphere 90:2467-2476. https://doi.org/10.1016/j.chemosphere.2012.11.012

Begum T, Dey S, Roy K, et al (2018) Assessment of surface water quality of the Turag River in $\begin{array}{llllll}\text { Bangladesh. } & \text { Res } & \mathrm{J} & \text { Chem } & \text { Environ }\end{array}$ https://www.researchgate.net/publication/323079506_Assessment_of_surface_water_qualit y_of_the_Turag_River_in_Bangladesh

Biterna M, Voutsa D (2005) Polychlorinated biphenyls in ambient air of NW Greece and in particulate emissions. Environ Int 31:671-677. https://doi.org/10.1016/j.envint.2004.11.004 
Bjermo H, Darnerud PO, Lignell S, et al (2013) Fish intake and breastfeeding time are associated with serum concentrations of organochlorines in a Swedish population. Environ Int 51:8896. https://doi.org/10.1016/j.envint.2012.10.010

Chi KH, Chang MB, Kao SJ (2007) Historical trends of PCDD/Fs and dioxin-like PCBs in sediments buried in a reservoir in Northern Taiwan. Chemosphere 68:1733-1740. https://doi.org/10.1016/j.chemosphere.2007.03.043

Ching YC, Lee YH, Toriman ME, et al (2015) Effect of the big flood events on the water quality of the Muar River, Malaysia. Sustain Water Resour Manag 1:97-110. https://doi.org/10.1007/s40899-015-0009-4

Cui S, Fu Q, Guo L, et al (2016) Spatial-temporal variation, possible source and ecological risk of PCBs in sediments from Songhua River, China: Effects of PCB elimination policy and reverse management framework. Mar Pollut Bull 106:109-118. https://doi.org/10.1016/j.marpolbul.2016.03.018

Cui X, Dong J, Huang Z, et al (2020) Polychlorinated biphenyls in the drinking water source of the Yangtze River: characteristics and risk assessment. Environ Sci Eur 32:. https://doi.org/10.1186/s12302-020-00309-6

Dodoo DK, Essumang DK, Jonathan JWA, Bentum JK (2012) Polychlorinated biphenyls in coastal tropical ecosystems: Distribution, fate and risk assessment. Environ Res 118:16-24. https://doi.org/10.1016/j.envres.2012.07.011

Eqani SAMAS, Malik RN, Zhang G, et al (2012) Polychlorinated biphenyls (PCBs) in the sediments of the River Chenab, Pakistan. Chem Ecol 28:327-339. https://doi.org/10.1080/02757540.2012.667085 
412 Erickson MD, Kaley RG (2011) Applications of polychlorinated biphenyls. Environ Sci Pollut Res

413 18:135-151. https://doi.org/10.1007/s11356-010-0392-1

414 Farooq S, Eqani S Ali-Musstjab-Akber-Shah, Malik RN, et al (2011) Occurrence, finger printing 415 and ecological risk assessment of polycyclic aromatic hydrocarbons (PAHs) in the Chenab 416 River, Pakistan. J Environ Monit 13:3207-3215. https://doi.org/10.1039/c1em10421g

417 Ferdousi A, Rahman MM, Rob MA, Hasan MM (2020) Researches in effluence and environmental 418 flow of turag river - A review. AIUB J Sci Eng 19:25-32. 419 http://ajse.aiub.edu/index.php/ajse/article/view/50

420 Gakuba E, Moodley B, Ndungu P, Birungi G (2015) Occurrence and significance of 421 polychlorinated biphenyls in water, sediment pore water and surface sediments of Umgeni 422 River, KwaZulu-Natal, South Africa. Environ Monit Assess 187:568. $423 \quad$ https://doi.org/10.1007/s10661-015-4790-1

424 Habibullah-Al-Mamun M, Ahmed MK, Islam MS, et al (2019) Seasonal-spatial distributions, 425 congener profile, and risk assessment of polychlorinated biphenyls (PCBS) in the surficial

Hellar-Kihampa H, Wael KD, Lugwisha E, et al (2013) Spatial monitoring of organohalogen compounds in surface water and sediments of a rural-urban river basin in Tanzania. Sci Total Environ 447:186-197. https://doi.org/10.1016/j.scitotenv.2012.12.083

431 Hossain S, Chowdhury MAI (2019) Hydro-morphology monitoring, water resources development 432 and challenges for Turag River at Dhaka in Bangladesh. Climate Change 5(17): 34-40. 433 https://www.researchgate.net/publication/328161887_Hydro- 

morphology_monitoring_water_resources_development_and_challenges_for_Turag_River_ at_Dhaka_in_Bangladesh

Islam J, Akter S, Bhowmick A, et al (2018) Hydro-environmental pollution of Turag river in Bangladesh. Bangladesh J Sci Ind Res 53:161-168. https://doi.org/10.3329/bjsir.v53i3.38261

Jafarabadi AR, Bakhtiari AR, Mitra S, et al (2019) First polychlorinated biphenyls (PCBs) monitoring in seawater, surface sediments and marine fish communities of the Persian Gulf: Distribution, levels, congener profile and health risk assessment. Environ Pollut 253:78-88. https://doi.org/10.1016/j.envpol.2019.07.023

Kakareka S, Kukharchyk T (2005) Sources of PCB emissions. EMEP/CORNAIR Emission Inventory Guidebook pp $57-69$. https://www.eea.europa.eu/publications/EMEPCORINAIR5/Sources_of_PCB_emissions.pd f/view

Kampire E, Rubidge G, Adams JB (2017) Characterization of polychlorinated biphenyls in surface sediments of the north end lake, port elizabeth, South Africa. Water SA 43:646-654. https://doi.org/10.4314/wsa.v43i4.12

Kanzari F, Syakti AD, Asia L, et al (2014) Distributions and sources of persistent organic pollutants (aliphatic hydrocarbons, PAHs, PCBs and pesticides) in surface sediments of an industrialized urban river (Huveaune), France. Sci Total Environ 478:141-151. https://doi.org/10.1016/j.scitotenv.2014.01.065

Kilunga PI, Sivalingam P, Laffite A, et al (2017) Accumulation of toxic metals and organic micropollutants in sediments from tropical urban rivers, Kinshasa, Democratic Republic of the Congo. Chemosphere 179:37-48. https://doi.org/10.1016/j.chemosphere.2017.03.081 
Kumar B, Kumar S, Sharma CS (2013) Ecotoxicological Risk Assessment of Polychlorinated Biphenyls (PCBs) in Bank Sediments from along the Yamuna River in Delhi, India. Hum Ecol Risk Assess 19:1477-1487. https://doi.org/10.1080/10807039.2012.723181

Li WH, Tian YZ, Shi GL, et al (2012) Source and risk assessment of PCBs in sediments of Fenhe reservoir and watershed, China. J Environ Monit 14:1256-1263. https://doi.org/10.1039/c2em10983b

Liber Y, Mourier B, Marchand P, et al (2019) Past and recent state of sediment contamination by persistent organic pollutants (POPs) in the Rhône River: Overview of ecotoxicological $\begin{array}{llll}\text { implications. } & \text { Sci } & \text { Total } & \text { Environ }\end{array}$ https://doi.org/10.1016/j.scitotenv.2018.07.340

Long ER, MacDonald DD (1998) Human and Ecological Risk Assessment: an Recommended Uses of Empirically Derived, Sediment Quality Guidelines for Marine and Estuarine Ecosystems PERSPECTIVE: Recommended Uses of Empirically Derived, Sediment Quality Guidelines for Marine and. Hum Ecol Risk Assess 4:1019-1039

Lu Q, Jürgens MD, Johnson AC, et al (2017) Persistent Organic Pollutants in sediment and fish in the River Thames Catchment (UK). Sci Total Environ 576:78-84. https://doi.org/10.1016/j.scitotenv.2016.10.067

Lv M, Luan X, Guo X, et al (2020) A national-scale characterization of organochlorine pesticides (OCPs) in intertidal sediment of China: Occurrence, fate and influential factors. Environ Pollut 257:113634. https://doi.org/10.1016/j.envpol.2019.113634

Majed N, Chawdhury MRA (2018) The Story of Turag River: How Severe Is the Pollution? World Environmental and Water Resources Congress 2018. 
Malik RN, Mehboob F, Ali U, et al (2014) Organo-halogenated contaminants (OHCs) in the sediments from the Soan River, Pakistan: OHCs(adsorbed TOC) burial flux, status and risk assessment. Sci Total Environ 481:343-351. https://doi.org/10.1016/j.scitotenv.2014.02.042

Mechlińska A, Wolska L, Namieśnik J, Wolska L (2010) Isotope-labeled substances in analysis of persistent organic pollutants in environmental samples. TrAC - Trends Anal Chem 29:820_ 831. https://doi.org/10.1016/j.trac.2010.04.011

Mochungong P, Zhu J (2015) DDTs, PCBs and PBDEs contamination in Africa, Latin America and South-southeast Asia-a review. AIMS Environ Sci 2:374-399. https://doi.org/10.3934/environsci.2015.2.374

Montuori P, Cirillo T, Fasano E, et al (2014) Spatial distribution and partitioning of polychlorinated biphenyl and organochlorine pesticide in water and sediment from Sarno River and Estuary, Southern Italy. Environ Sci Pollut Res 21:5023-5035. https://doi.org/10.1007/s11356-013-2419-x

Neamtu M, Ciumasu IM, Costica N, et al (2009) Chemical, biological, and ecotoxicological assessment of pesticides and persistent organic pollutants in the Bahlui River, Romania. Environ Sci Pollut Res Int 16 Suppl 1:76-85. https://doi.org/10.1007/s11356-009-0101-0

OCHA (2019) Bangladesh: Cyclone FANI Joint Situation Analysis. Humanitarian RESPONSE, United Nations Resident Coordinators $\quad$ Office. https://www.humanitarianresponse.info/en/operations/bangladesh/document/bangladeshcyclone-fani-joint-situation-analysis-13-may-2019. Accessed 25 February 2021 
Ormerod SJ, Tyler SJ, Jüttner I (2000) Effects of point-source PCB contamination on breeding performance and post-fledging survival in the dipper Cinclus cinclus. Environ Pollut 110:505-513. https://doi.org/10.1016/S0269-7491(99)00313-9

502

503

504

505

506

Rahman M, Rahman S, Chowdhury M, Fardous Z (2018) Impacts of Low Flows on Heavy Metal concentrations in Turag River Bangladesh. J Environ Sci Nat Resour 10:177-182. https://doi.org/10.3329/jesnr.v10i2.39032

Sarkar M, Islam JB, Akter S (2016) Pollution and ecological risk assessment for the environmentally impacted Turag River, Bangladesh. J Mater Environ Sci 7:2295-2304

Syed JH, Malik RN, Li J, et al (2014) Status, distribution and ecological risk of organochlorines (OCs) in the surface sediments from the Ravi River, Pakistan. Sci Total Environ 472:204211. https://doi.org/10.1016/j.scitotenv.2013.10.109

The Daily Star (2019) Bangladesh Weather: Heavy rainfall is likely to continue over Dhaka throughout the day today due to the influence of cyclonic storm Fani. https://www.thedailystar.net/city/news/heavy-rain-dhaka-today-1738513. Accessed 10 February 2021

Tian YZ, Li WH, Shi GL, et al (2013) Relationships between PAHs and PCBs, and quantitative source apportionment of PAHs toxicity in sediments from Fenhe reservoir and watershed. J Hazard Mater 248-249:89-96. https://doi.org/10.1016/j.jhazmat.2012.12.054

Toan VD, Quy NP (2015) Residues of Polychlorinated Biphenyls (PCBs) in Sediment from CauBay River and Their Impacts on Agricultural Soil, Human Health Risk in KieuKy Area, Vietnam. Bull Environ Contam Toxicol 95:177-182. https://doi.org/10.1007/s00128-015$1581-\mathrm{X}$ 
521 Wang W, Bai J, Zhang G, et al (2019) Occurrence, sources and ecotoxicological risks of 522 polychlorinated biphenyls (PCBs) in sediment cores from urban, rural and reclamation523 affected rivers of the Pearl River Delta, China. Chemosphere 218:359-367. $524 \quad$ https://doi.org/10.1016/j.chemosphere.2018.11.046

525 Zhang G, Bai J, Zhao Q, et al (2016) Heavy metals in wetland soils along a wetland-forming 526 chronosequence in the Yellow River Delta of China: Levels, sources and toxic risks. Ecol 527 Indic 69:331-339. https://doi.org/10.1016/j.ecolind.2016.04.042 


\section{Figures}

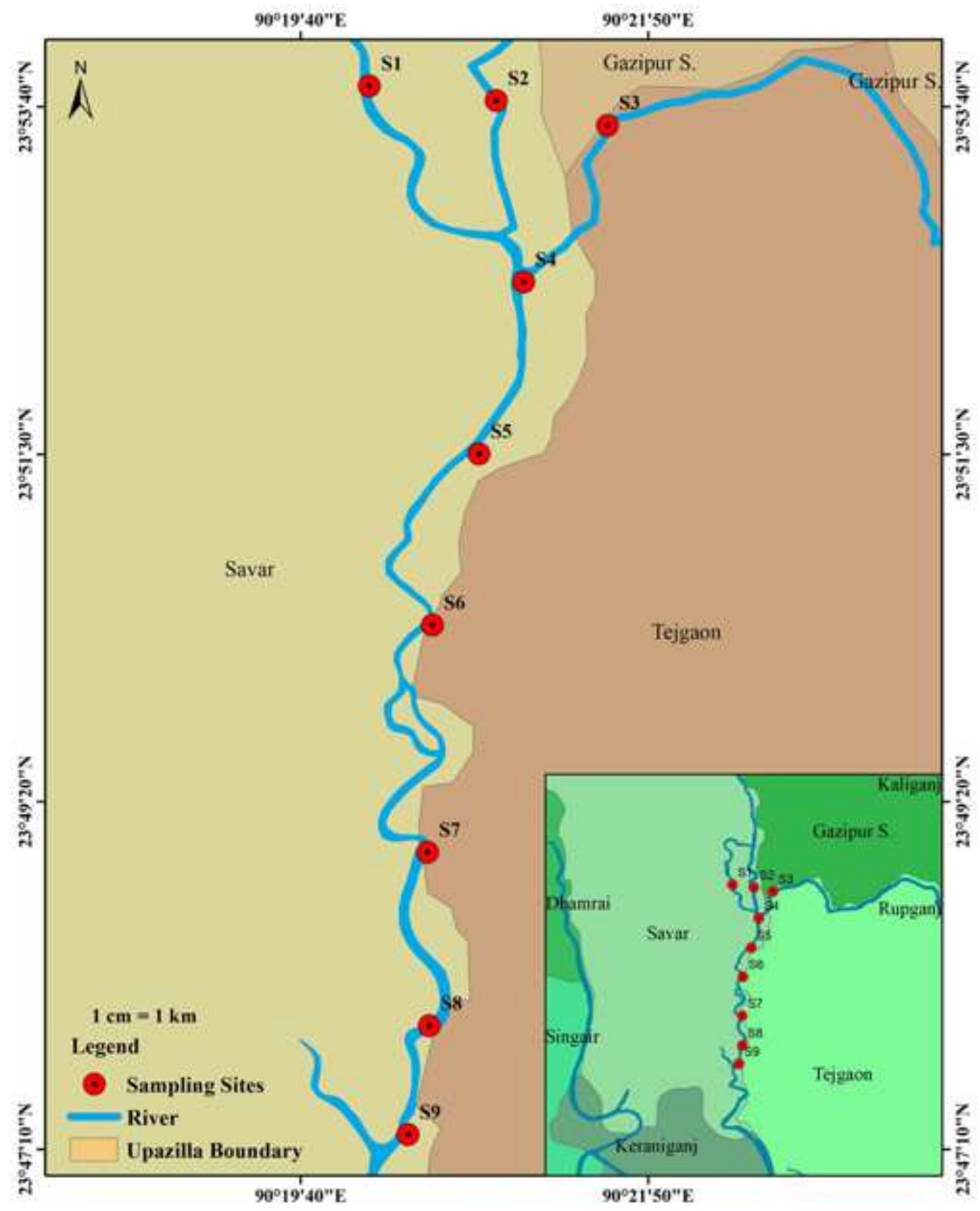

\section{Figure 1}

Sampling sites along the Turag River Note: The designations employed and the presentation of the material on this map do not imply the expression of any opinion whatsoever on the part of Research Square concerning the legal status of any country, territory, city or area or of its authorities, or concerning the delimitation of its frontiers or boundaries. This map has been provided by the authors. 
(a) - PCB $10 \square$ PCB $28 \square$ PCB $52 \square$ PCB $138 \square$ PCB $153 \square$ PCB 180

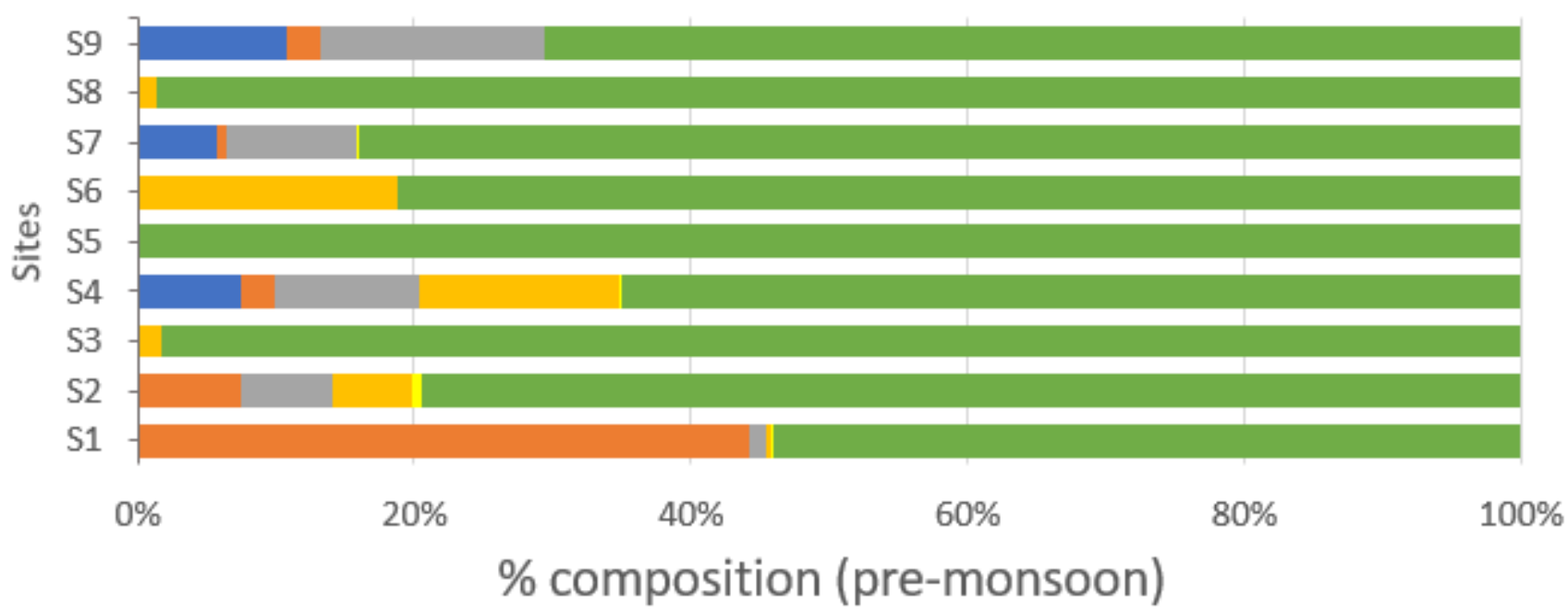

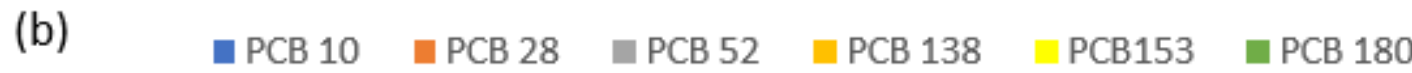

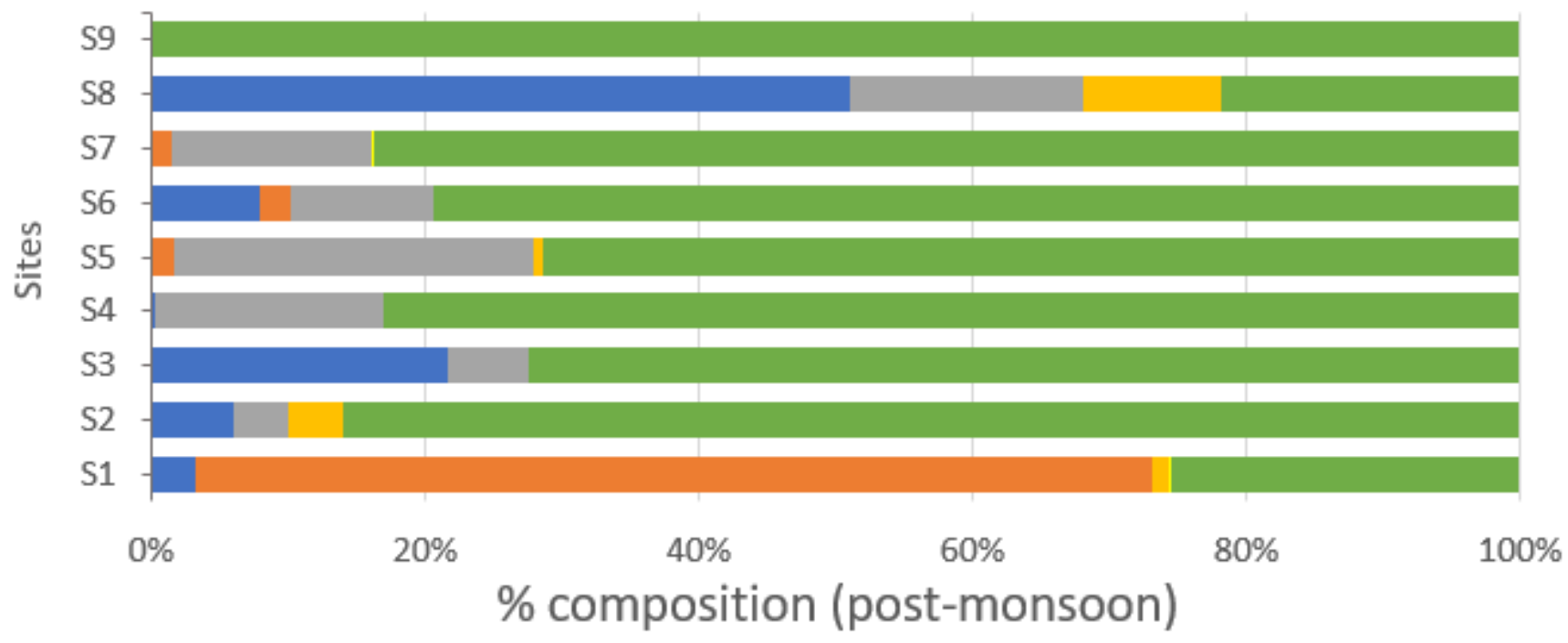

Figure 2

Composition (\%) of six PCB congeners in sediment samples of (a) pre-monsoon and (b) post-monsoon 


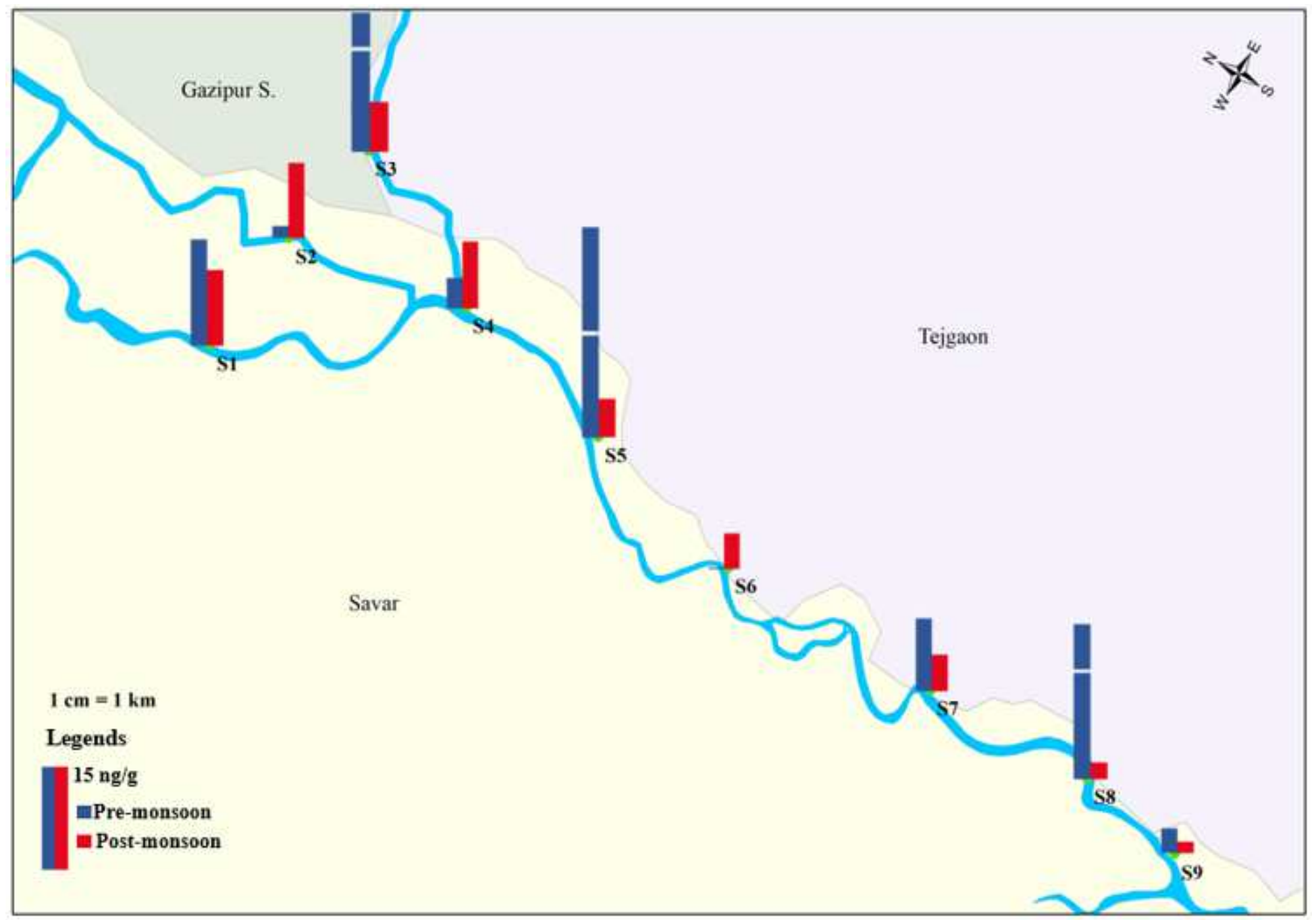

Figure 3

Distribution of total PCBs in surface sediment along the Turag River collected in post-monsoon and premonsoon Note: The designations employed and the presentation of the material on this map do not imply the expression of any opinion whatsoever on the part of Research Square concerning the legal status of any country, territory, city or area or of its authorities, or concerning the delimitation of its frontiers or boundaries. This map has been provided by the authors. 